\title{
LUMBAR SPONDYLOPTOSIS AFTER SEVERE POLYTRAUMA: A CASE REPORT
}

\author{
Nenad Koruga ${ }^{1,2}$, Anamarija Soldo Koruga ${ }^{2,3}$, Ivan Hećimovićc ${ }^{1,2}$, Goran Kondža ${ }^{4,5}$, \\ Žarko Bakran ${ }^{6,7}$, Vedran Zubčić ${ }^{7,8}$, Ante Rotim ${ }^{9}$ and Vinicius Trindade Gomes da Silva ${ }^{10}$ \\ ${ }^{1}$ Department of Neurosurgery, Osijek University Hospital Centre, Osijek, Croatia; \\ ${ }^{2}$ Department of Neurology and Neurosurgery, Faculty of Medicine, \\ Josip Juraj Strossmayer University of Osijek, Osijek, Croatia; \\ ${ }^{3}$ Department of Neurology, Osijek University Hospital Centre, Osijek, Croatia; \\ ${ }^{4}$ Department of Surgery, Osijek University Hospital Centre, Osijek, Croatia; \\ ${ }^{5}$ Department of Surgery, Urology, Orthopedics, Physical and Rehabilitation Medicine, \\ Faculty of Medicine, Josip Juraj Strossmayer University of Osijek, Osijek, Croatia; \\ ${ }^{6}$ Krapinske Toplice Special Hospital for Medical Rehabilitation, Krapinske Toplice, Croatia; \\ ${ }^{7}$ Faculty of Medicine, Josip Juraj Strossmayer University of Osijek, Osijek, Croatia; \\ ${ }^{8}$ Department of Maxillofacial Surgery, Osijek University Hospital Centre, Osijek, Croatia; \\ Faculty of Medicine, Josip Juraj Strossmayer University of Osijek, Croatia; \\ ${ }^{9}$ Department of Neurosurgery, Dubrava University Hospital, Zagreb, Croatia; \\ ${ }^{10}$ Department of Neurosurgery, Hospital das Clinicas, Faculty of Medicine, \\ University of Sao Paulo, Sao Paulo, Brazil
}

\begin{abstract}
SUMMARY - A rare case of thoracolumbar spondyloptosis after a severe polytraumatic event is presented. Spondyloptosis accounts for a minor proportion of all spine trauma cases and is usually accompanied by complete neurological deficit. A 48-year-old man suffered severe polytrauma after having been hit by a truck at the work place. Radiographic scanning revealed multiple traumatic injuries and spondyloptosis at the L1/L2 level in coronal plane. However, despite extensive injuries, ASIA score was estimated as $\mathrm{D}$. The patient underwent urgent multidisciplinary surgery due to severe head injuries. The next surgery was performed to stabilize the thoracolumbar segment and to preserve neurological functions. The surgery included implantation of transpedicular titanium screws via posterior approach. Good postoperative recovery was achieved during early postoperative rehabilitation at our Department, which was estimated as ASIA score D. In conclusion, prompt operative treatment to achieve neural integrity and early rehabilitation should be considered as the gold standard in such complicated injuries. Postoperative recovery largely depends on the quality of rehabilitation, which leads to improvement of patient self-care and normal social and psychological functions. In our case, the good preoperative neurological status of the patient also contributed to better postoperative outcome.
\end{abstract}

Key words: Craniotomy; Spondyloptosis; Hemorrhage, subarachnoid; Neurological rehabilitation; Blindness

\section{Introduction}

Spondyloptosis is defined as $100 \%$ or greater subluxation of a superior vertebral body on an inferior one in the coronal or sagittal plane secondary to an injury ${ }^{1}$. Spondyloptosis results in one spinal segment being shifted in relationship to the adjacent segment ${ }^{2}$, which
Correspondence to: Nenad Koruga, MD, Department of Neurosurgery, Osijek University Hospital Centre, Josipa Huttlera 4, HR-31000 Osijek

E-mail: nkoruga@gmail.com

Received December 23, 2019, accepted July 24, 2020 
leads to severe biomechanical instability caused by complete disruption of anatomic elements of the vertebral column and the adjacent paravertebral soft tissues $^{3}$. Complete neurological deficit is presented in almost $80 \%$ of cases ${ }^{4}$. High-velocity injury is the most common mechanism of injury that results in spondyloptosis with associated injuries of other anatomic regions ${ }^{5}$. The aim of this case report is to present a rare case of spondyloptosis in the thoracolumbar region after severe trauma.

\section{Case Report}

A 48-year-old man suffered from severe polytraumatic injury after collision with a dump truck. Initially, the patient was treated in another institution where computed tomography (CT) scan revealed an impressive fracture of the left-sided temporal bone and epidural hemorrhage at the same site. Also, CT scan revealed subarachnoid hemorrhage located in the leftsided sylvian fissure and ipsilateral subdural hemorrhage in the region of frontal and temporal lobe of the brain. Multiple viscerocranial fractures were estimated as Le Fort III. The patient also suffered traumatic avulsion of the left-sided optic nerve. According to verified head injuries on CT scan, left-sided pterional craniotomy was performed. Epidural and subdural hemorrhages were evacuated and small bony fragments due to impressive fracture were removed. Multiple dural lacerations were sutured to prevent further cerebrospinal fluid (CSF) leak. During the same operative procedure in general anesthesia, injury of the left-sided eye bulb was treated by ophthalmologists, while viscerocranial injuries were treated by maxillofacial surgeons. CT scan of the thoracic and lumbar region revealed complete lateral displacement of the L2 vertebral body as related to L1, with posterior shear injury of L2. CT scanning showed almost parallel vertebral bodies of $\mathrm{L} 1$ and L2, presented as 'double vertebrae sign' (Fig. 1). Transpedicular screw fixation was postponed due to multiple organ injuries and clinical instability of the patient, which was observed at the Intensive Care Unit (ICU). Neurological assessment prior to transpedicular screw fixation revealed muscle strength grade $3 / 5$ in both lower extremities and spinal injury was estimated as ASIA score D. Sensory deficit was noted at the level of the left-sided anterior thigh. According to CT scan evaluation of thoracic and lumbar spine, thoraco-

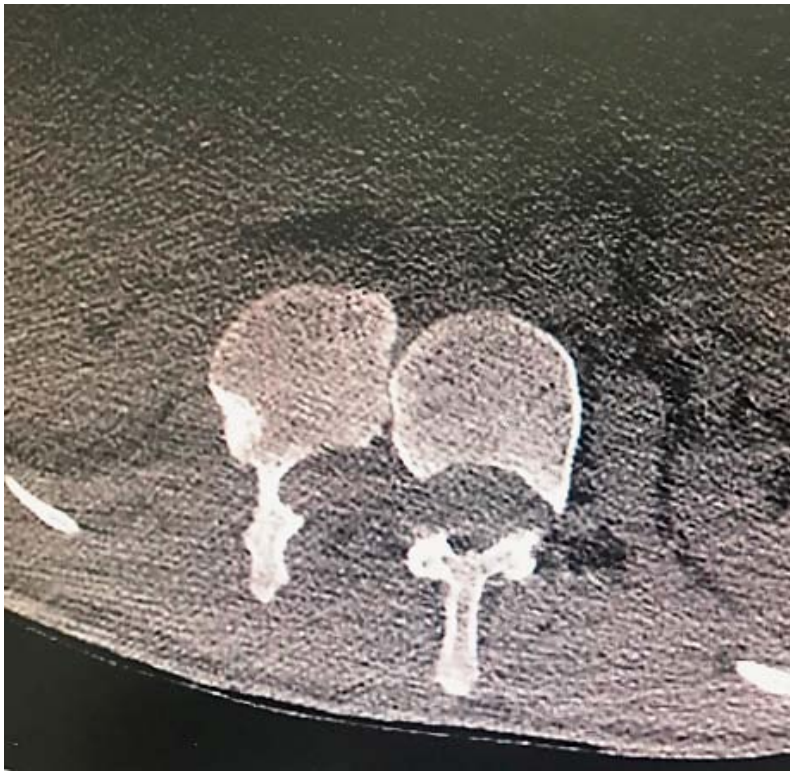

Fig. 1. Computed tomography scan revealed 'double vertebrae sign"' in axial plane.

lumbar approach and spondylodesis was performed from T12 to L4 due to lateral spondyloptosis of the L2 vertebral body (Fig. 2). Also, L2 laminectomy was performed due to multiple bony fragments with the possibility of violation of spinal canal and injury of neural structures within it. Transpedicular screws (Medtronic Legacy ${ }^{\circledR}$ spinal system) were placed in T12, L1, L3 and L4 pedicles bilaterally and the right-sided pedicle of the L2 vertebra, which remained intact after the trauma. Bilateral longitudinal rods were anchored with transverse rod at the level of laminectomy. Transection of spinal cord and CSF leak were not observed during surgery. Intraoperative $\mathrm{x}$-ray revealed excellent placement of the screws and consequent spinal reposition. Alignment of the posterior spinal elements was achieved. After both surgical procedures, the patient was transferred to the ICU, where he stayed for three weeks and then transferred to the Department of Neurosurgery ward. During postoperative care at our Department, early rehabilitation was initiated. Postoperative $\mathrm{CT}$ scan with $3 \mathrm{D}$ visualization revealed proper reconstruction of lumbar spondyloptosis (Fig. 3). Upon discharge from the Department, the patient had left-sided blindness and postoperative spinal injury was estimated as ASIA score D. Sensory deficit of the left-sided anterior thigh remained unchanged postoperatively. 


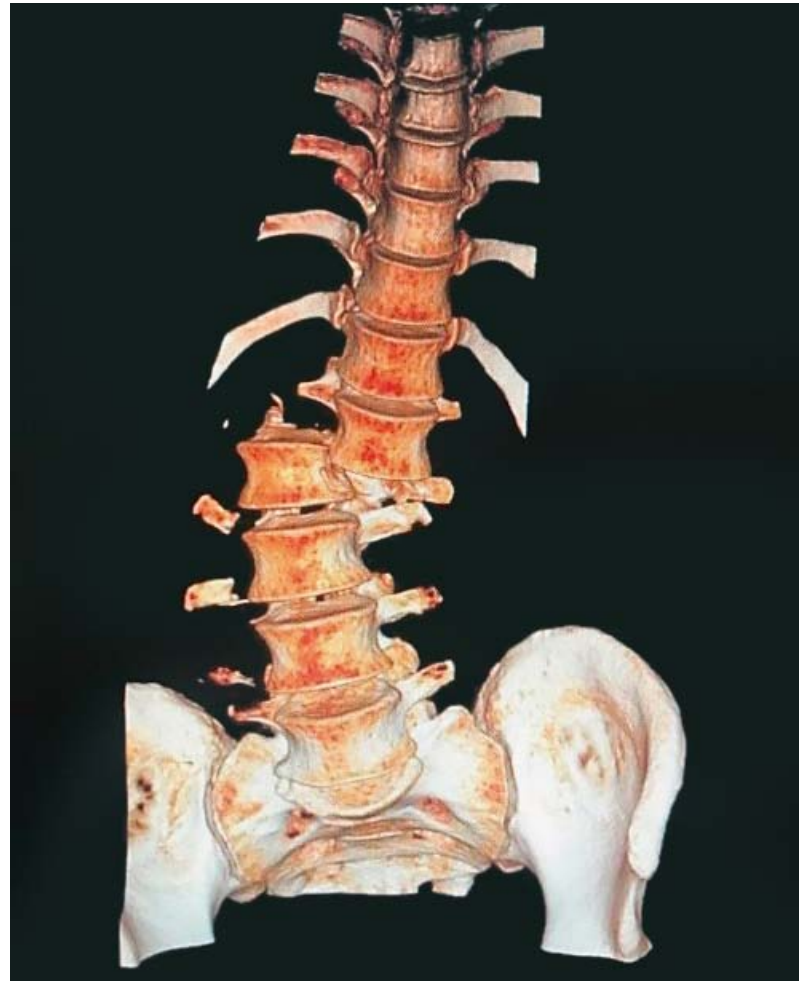

Fig. 2. Preoperative posttraumatic 3D computed tomography scan of thoraco-lumbar spine showed spondyloptosis at the L1-L2 level in coronal plane.

\section{Postoperative follow-up}

The patient was admitted to our Department six months after the injury and surgical treatment. During hospitalization, the patient underwent follow-up $\mathrm{x}$-ray scan, which revealed excellent postoperative placement of transpedicular screws and rods and concomitant postoperative vertebral alignment. Electromyography showed radiculopathy of L5 and S1 bilaterally, while somatosensory evoked potentials following tibial nerve stimulation revealed preserved conduction velocities in both tibial nerves. The patient could walk independently with approximate walking distance of threehundred meters and had normal bladder control. The patient held test position against moderate to strong pressure on both lower extremities during manual muscle testing, which was graded as $4+$.

\section{Discussion}

Around $90 \%$ of all spine fractures involve the thoracolumbar region ${ }^{6}$. The majority of all thoracolumbar injuries are located at T11 to L2 levels, which are more

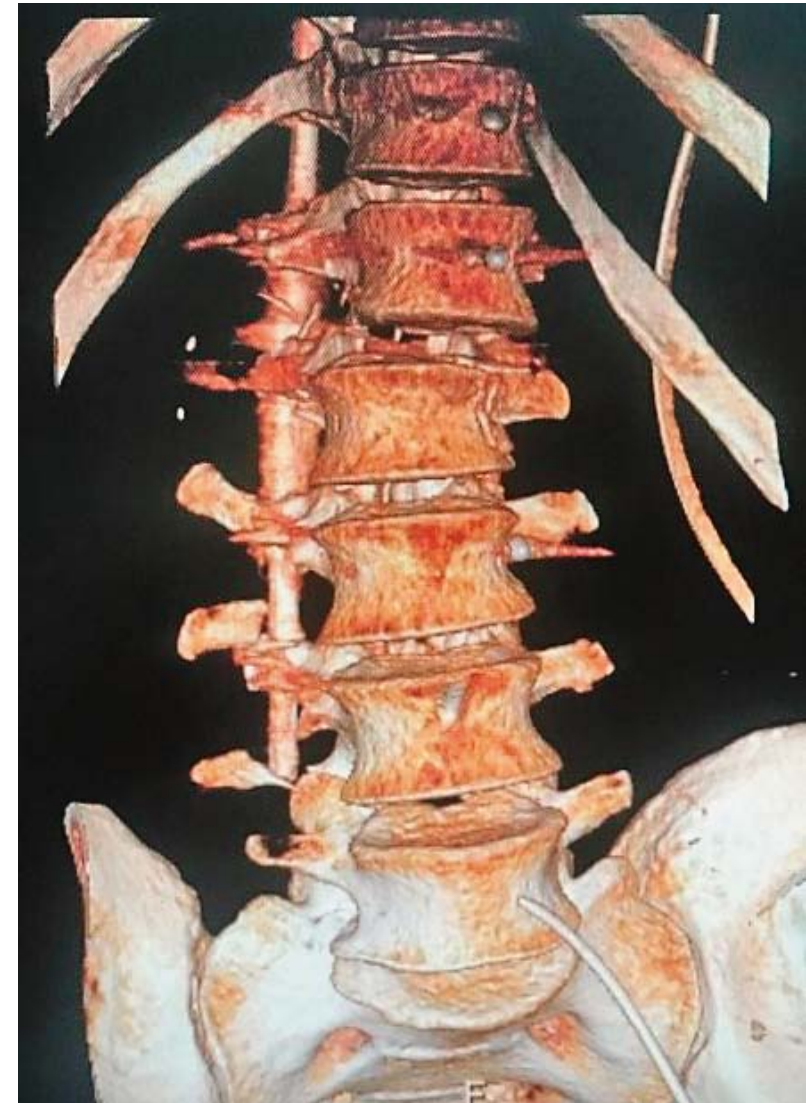

Fig. 3. Postoperative 3D computed tomography scan revealed proper spinal alignment.

susceptible to stress due to biomechanical weakness ${ }^{7}$. The causes of thoracolumbar fractures are different and depend on patient age. High-energy trauma fractures are more likely to occur in younger patients, such as motor vehicle accidents or falling injuries. Elderly patients with cognitive impairment and osteoporosis usually suffer simple falls even from standing position to the ground, which can result in spinal fractures ${ }^{8,9}$. In severe trauma, complications such as paralysis or deformity lead to limitations in daily activities or difficulties connected to returning to work due to posttraumatic chronic pain ${ }^{10}$. Spondyloptosis is defined as $100 \%$ listhesis of adjoining vertebrae ${ }^{1}$ and is associated with complete neurological deficit in $80 \%$ of cases ${ }^{4}$. Denis classification recognizes spondyloptosis as a very unstable injury, which involves all three columns of the spine. In 1994, Magerl et al. published a classification system based on instability of the spine, pathomorphological criteria, increasing injury, and instability. According to their classification, spinal fractures are catego- 
rized as follows: (A) compression fractures which are most common and account for about $66 \%$ of cases; (B) distraction; and $(\mathrm{C})$ fracture-dislocation with rotation injury $^{11}$. In a biomechanical study of spine injuries, Roaf $^{12}$ found the spine to be highly susceptible to injury in all three columns when hyperflexion or hyperextension was combined with rotational or shear forces. As all three columns are affected, these injuries are considered unstable, which can result in additional spinal cord injury ${ }^{13}$. Formerly used classifications were not insufficient to describe injury severity, pathogenesis and biomechanical forces based on clinical, radiological and neurological features, thus none of the above mentioned systems has been universally accepted ${ }^{14}$. Reinhold et al. revised Magerl's AO classification, which defined injury patterns with concomitant mechanical failures of the spinal column. The revised classification of thoracolumbar injuries was based on morphological characteristics of the vertebral column after traumatic injuries identified on diagnostic images, primarily multiplanar CT scan assessment. The three newly proposed models of spinal column integrity failure are classified as follows: (A) axial load compression injury of anterior elements with preserved posterior ligamentous apparatus; (B) injury of posterior ligamentous elements; and (C) injury of anterior and posterior elements resulting in displacement ${ }^{15}$. According to the available literature, Mishra et al. have reported on the largest group of twenty patients with traumatic spondyloptosis, all of them graded as ASIA A upon admission. There was no improvement after surgical treatment and five deaths occurred during the follow-up. In their study, the most common site of injury was thoracolumbar spine ${ }^{16}$. Thoracolumbar spine injuries are predisposed due to the mechanical transition zone between the rigid thoracic spine segment and more mobile lumbar spine segment ${ }^{17}$. Yadla et al. published a retrospective review of five patients, four of them suffering from sagittal-plane spondyloptosis and graded as ASIA A and one patient with coronal-plane spondyloptosis graded as ASIA C. They describe the first case of thoracolumbar spondyloptosis without complete paraplegia and further neurological recovery during the follow-up period ${ }^{18}$. The case of our patient was similar to the aforementioned one and the authors did not find any similar case of improved neurological recovery of thoracolumbar spondyloptosis since the case reported by Yadla et al. ${ }^{18}$. In both cases, the intact vertebral bodies were found with complete lateral displace- ment of L1 to L2 vertebral body. This suggests a sheartype mechanism with a coronally or laterally directed vector force ${ }^{19}$. Bellew and Bartholomew have reported the first case of lumbar spondyloptosis in the English literature. They managed their case with delay in time, in a similar fashion to ours due to the patient's complicated condition. They also report complete postoperative neurological recovery ${ }^{20}$. Whenever possible, spondyloptosis should be reduced early to increase the chances of neurological recovery ${ }^{21}$. Mishra et al. report that all patients in their group were operated on via the posterior route in a single act, but complete alignment could not have been achieved in four patients operated on for spondyloptosis. Nevertheless, spinal column fixation and possibility of early rehabilitation were achieved ${ }^{16}$. Early rehabilitation and mobilization of patients remained the ultimate postoperative goal. Complexity of spondyloptotic injury, its surgical treatment and postoperative rehabilitation management open long-term issues regarding postoperative outcome. Furthermore, it represents an obstacle in post-rehabilitation social and working terms in these patients. The severity of spinal cord injury and complexity of operative treatment in terms of posttraumatic spine stabilization should point to the onset of early postoperative rehabilitation, which is essential for recovery and preserving patient neurological functions. Spondyloptosis with possible posttraumatic neurological deficit as the most complex spinal injury will remain a challengeable surgical entity in the foreseeable future despite modern treatment options and prompt surgical approach.

\section{Conclusion}

Prompt operative treatment to achieve neural integrity and early rehabilitation should be considered as the gold standard in such complicated injuries. Postoperative recovery largely depends on the quality of rehabilitation, which leads to improvement of patient self-care and normal social and psychological functions. In our case, a good preoperative neurological status of the patient also led to better postoperative outcome.

\section{References}

1. Meyerding HW. Spondylolisthesis as an etiologic factor in backache. JAMA. 1938;111(22):1971-6. 10.1001/jama.1938. 02790480001001. doi: 10.1001/jama.1938.02790480001001 
2. E1-Khoury G, Whitten C. Trauma to the upper thoracic spine: anatomy, biomechanics, and unique imaging features. AJR Am J Roentgenol.1993;160(1):95-102.10.2214/ajr.160.1.8416656. doi: 10.1186/1752-1947-8-453

3. Gharib A, Postel G, Mirza S, Mann F. A thoracic spine translation injury with lateral facet dislocation. AJR Am J Roentgenol. 2002;178(6):1450. doi: 10.2214/ajr.178.6.1781450.

4. Shapiro S, Abel T, Rodgers RB. Traumatic thoracic spinal fracture dislocation with minimal or no cord injury. Report of four cases and review of the literature. J Neurosurg. 2002;96 (3 Suppl):333-7. doi.org/10.3171/spi.2002.96.3.0333

5. Meneghini RM, DeWald CJ. Traumatic posterior spondyloptosis at the lumbosacral junction. A case report. J Bone Joint Surg Am. 2003;85-A:346-50. doi: 10.1007/s00264-010-1190-6

6. DeWald RL. Burst fractures of the thoracic and lumbar spine. Clin Orthop Relat Res. 1984;189:150-61. PMID: 6478692

7. Gertzbein SD. Scoliosis Research Society. Multicenter spine fracture study. Spine (Phila Pa 1976). 1992;17:528-40. doi: 10.1097/00007632-199205000-00010

8. Rockwood CA, Green DP, Bucholz RW. Rockwood and Green's Fractures in Adults. Philadelphia: Lippincott Williams \& Wilkins; 2006.

9. Kim DH, Silber JS, Albert TJ. Osteoporotic vertebral compression fractures. Instr Course Lect. 2003;52:541-50. PMID: 12690880

10. McLain RF. Functional outcomes after surgery for spinal fractures: return to work and activity. Spine (Phila Pa 1976). 2004;29:470-7. doi: 10.1097/01.brs.0000092373.57039.fc

11. Magerl F, Aebi M, Gertzbein SD, et al. A comprehensive classification of thoracic and lumbar injuries. Eur Spine J. 1994; 3:184-201. doi: $10.1007 / \mathrm{bf02221591}$

12. Roaf R. A study of the mechanics of spinal injuries. J Bone Joint Surg Br. 1960;42(8):810-23.

13. Denis F. The three-column spine and its significance in the classification of acute thoracolumbar spinal injuries. Spine
(Phila Pa 1976). 1983;8:817-31. doi: 10.1097/00007632198311000-00003

14. Mirza SK, Mirza AJ, Chapman JR, Anderson PA. Classifications of thoracic and lumbar fractures: rationale and supporting data. J Am Acad Orthop Surg. 2002;10:364-77. doi: 10.5435/ 00124635-200209000-00008

15. Reinhold M, Audigé L, Schnake KJ, Bellabarba C, Dai LY, Oner FC. AO spine injury classification system: a revision proposal for the thoracic and lumbar spine. Eur Spine J. 2013 Oct;22(10):2184-201. doi: 10.1007/s00586-013-2738-0

16. Mishra A, Agrawal D, Gupta D, Sinha S, Satyarthee GD, Singh PK. Traumatic spondyloptosis: a series of 20 patients. J Neurosurg Spine. 2015;22:647-52. doi: 10.3171/2014.10. SPINE1440

17. Bohlman HH. Treatment of fractures and dislocations of the thoracic and lumbar spine. J Bone Joint Surg Am. 1985;67: 165-9. PMID: 3881446

18. Yadla S, Lebude B, Tender GC, Sharan AD, Harrop JS, Hilibrand AS, et al. Traumatic spondyloptosis of the thoracolumbar spine. J Neurosurg Spine. 2008;9:145-51. doi: 10.3171/SPI/ 2008/9/8/145

19. Lee HM, Kim HS, Kim DJ, Suk KS, Park JO, Kim NH. Reliability of magnetic resonance imaging in detecting posterior ligament complex injury in thoracolumbar spinal fractures. Spine. 2000;25:2079-84. doi: 10.1097/00007632-20000815000012

20. Bellew MP, Bartholomew BJ. Dramatic neurological recovery with delayed correction of traumatic lumbar spondyloptosis. Case report and review of the literature. J Neurosurg Spine. 2007;66:606-10. doi: 10.3171/spi.2007.6.6.16

21. Lu X, Hou C, Yuan W, Zhang Z, Chen A. Complete traumatic anterior dislocation of the lumbosacral joint: a case report. Spine. 2009;34(14):E488-E492. doi: 10.1097/BRS.0b $013 \mathrm{e} 3181 \mathrm{a} 8 \mathrm{cdad}$

Sažetak

\title{
LUMBALNA SPONDILOPTOZA NAKON TEŠKE POLITRAUME: PRIKAZ SLUČAJA
}

\author{
N. Koruga, A. Soldo Koruga, I. Hecimović, G. Kondža, Ž. Bakran, V. Zubčiç, A. Rotim i V. Trindade Gomes da Silva
}

Prikazuje se rijedak slučaj torako-lumbalne spondiloptoze nakon teške politraume. Manji udio svih trauma kralježnice odnosi se na spondiloptoze koje su najčešće popraćene potpunim neurološkim deficitom. Muškarac u dobi od 48 godina na radnom mjestu zadobio je politraumatske ozljede nakon udarca kamiona. Radiološka obrada pokazala je višestruke traumatske ozljede i spondiloptozu segmenta L 1/L 2 u koronarnoj projekciji. Unatoč ovoj opsežnoj traumi kralježnice ozljeda je prema ljestvici ASIA procijenjena kao D. Bolesniku je učinjen hitni multidisciplinski operacijski zahvat u svrhu zbrinjavanja teških ozljeda glave. Sljedećoj operaciji pristupljeno je radi stabilizacije torako-lumbalnog segmenta i s ciljem očuvanja neuroloških funkcija. Operacija je učinjena uobičajenim stražnjim pristupom te implantacijom transpedikularnih vijaka. Zadovoljavajući poslijeoperacijski oporavak postignut je tijekom rane poslijeoperacijske rehabilitacije u Klinici, procijenjen kao ASIA D. Izvrstan poslijeoperacijski oporavak potvrđen je daljnjom ambulantnom kontrolom bolesnika, uz učinjene neurološke testove. Poslijeoperacijska neurorehabilitacija smatra se nužnom za što bolji oporavak fizioloških funkcija u ovakvim životno ugrožavajućim nesrećama.

Ključne riječi: Kraniotomija; Spondiloptoza; Subarahnoidno krvarenje; Neurološka rehabilitacija; Sljepoća 